\title{
ECHO: Developing a Multi-Hazard Incident Risk Assessment Tool for Swiftwater and Flood Rescue
}

\section{By Steve Glassey MEmergMgt PGCPM GCTSS CEM ${ }^{*}$}

\author{
steve@publicsafety.institute
}

\begin{abstract}
Currently there is no multi-hazard risk assessment tool for determining the level of complexity to swiftwater and flood rescue incidents. Traditionally, the International Scale of River Difficulty is used but it is primarily for paddlers for use in a recreational context, without much consideration to the multitude of hazards faced in swiftwater and flood rescue environments. In response to this gap, the ECHO risk assessment tool has been developed and undergone initial testing. This tool provides for simple and rapid codification of multiple hazards and response considerations and is globally applicable. The tool also assigns a final risk assessment colour making the interpretation of the assessment easy to understand and communicate. Though the proposed tool shows potential, further research is needed before it should be operationalised.
\end{abstract}

\section{Keywords}

Assessment; echo; flood; rescue; risk; swiftwater; tool; srirac

\section{Introduction}

Throughout the world, the International Scale of River Difficulty (ISRD) [1] has become the standard to rate the degree of difficulty and risk to paddlers (Table 1). The scale is part of the American Whitewater Safety Code and was developed by an experienced cadre of whitewater experts from the American Whitewater, a national non-profit river conservation organisation founded in 1954.

It has played a vital role in consistently providing a tool across different countries to rate river paddling complexity including specific features or sections within. There are minor variations in its application outside the United States, with some countries like New Zealand referring to the scale as "Grades" (using numbers 1-6) [2], not the prescribed "Classes" (using Roman numerals I-VI) which is inconsistent to the international terminology and may raise confusion over whether another international system exist. Likewise, it has been referred to as the International Whitewater Scale, International River Grading System, and International River Rating System adding to the confusion.

Either way, the scale ranges from one to six, with six being considered extreme. 
ECHO: Developing a multi-hazard incident risk assessment tool for swiftwater and flood rescue

\begin{tabular}{|c|c|}
\hline $\begin{array}{l}\text { Class I: } \\
\text { Easy }\end{array}$ & $\begin{array}{l}\text { Fast moving water with riffles and small waves. Few obstructions, all obvious and } \\
\text { easily missed with little training. Risk to swimmers is slight; self-rescue is easy. }\end{array}$ \\
\hline $\begin{array}{l}\text { Class II: } \\
\text { Novice }\end{array}$ & $\begin{array}{l}\text { Straightforward rapids with wide, clear channels which are evident without scouting. } \\
\text { Occasional manoeuvring may be required, but rocks and medium-sized waves are } \\
\text { easily avoided by trained paddlers. Swimmers are seldom injured and group } \\
\text { assistance, while helpful, is seldom needed. Rapids that are at the upper end of this } \\
\text { difficulty range are designated Class II+. }\end{array}$ \\
\hline $\begin{array}{l}\text { Class III: } \\
\text { Intermediate }\end{array}$ & $\begin{array}{l}\text { Rapids with moderate, irregular waves which may be difficult to avoid and which can } \\
\text { swamp an open canoe. Complex manoeuvres in fast current and good boat control in } \\
\text { tight passages or around ledges are often required; large waves or strainers may be } \\
\text { present but are easily avoided. Strong eddies and powerful current effects can be } \\
\text { found, particularly on large-volume rivers. Scouting is advisable for inexperienced } \\
\text { parties. Injuries while swimming are rare; self-rescue is usually easy, but group } \\
\text { assistance may be required to avoid long swims. Rapids that are at the lower or upper } \\
\text { end of this difficulty range are designated Class III- or Class III+ respectively. }\end{array}$ \\
\hline $\begin{array}{l}\text { Class IV: } \\
\text { Advanced }\end{array}$ & $\begin{array}{l}\text { Intense, powerful but predictable rapids requiring precise boat handling in turbulent } \\
\text { water. Depending on the character of the river, it may feature large, unavoidable } \\
\text { waves and holes or constricted passages demanding fast manoeuvres under pressure. } \\
\text { A fast, reliable eddy turn may be needed to initiate manoeuvres, scout rapids, or rest. } \\
\text { Rapids may require "must make" moves above dangerous hazards. Scouting may be } \\
\text { necessary the first time down. Risk of injury to swimmers is moderate to high, and } \\
\text { water conditions may make self-rescue difficult. Group assistance for rescue is often } \\
\text { essential but requires practiced skills. For kayakers, a strong roll is highly } \\
\text { recommended. Rapids that are at the lower or upper end of this difficulty range are } \\
\text { designated Class IV- or Class IV+ respectively. }\end{array}$ \\
\hline $\begin{array}{l}\text { Class V: } \\
\text { Expert }\end{array}$ & $\begin{array}{l}\text { Extremely long, obstructed, or very violent rapids which expose a paddler to added } \\
\text { risk. Drops may contain large, unavoidable waves and holes or steep, congested } \\
\text { chutes with complex, demanding routes. Rapids may continue for long distances } \\
\text { between pools, demanding a high level of fitness. What eddies exist may be small, } \\
\text { turbulent, or difficult to reach. At the high end of the scale, several of these factors } \\
\text { may be combined. Scouting is recommended but may be difficult. Swims are } \\
\text { dangerous, and rescue is often difficult even for experts. Proper equipment, extensive } \\
\text { experience, and practiced rescue skills are essential. } \\
\text { Because of the large range of difficulty that exists beyond Class IV, Class V is an open- } \\
\text { ended, multiple-level scale designated by class } 5.0,5.1,5.2 \text {, etc. Each of these levels is } \\
\text { an order of magnitude more difficult than the last. That is, going from Class } 5.0 \text { to } \\
\text { Class } 5.1 \text { is a similar order of magnitude as increasing from Class IV to Class } 5.0 \text {. }\end{array}$ \\
\hline $\begin{array}{l}\text { Class VI: } \\
\text { Extreme and } \\
\text { Exploratory } \\
\text { Rapids }\end{array}$ & $\begin{array}{l}\text { Runs of this classification are rarely attempted and often exemplify the extremes of } \\
\text { difficulty, unpredictability and danger. The consequences of errors are severe, and } \\
\text { rescue may be impossible. For teams of experts only, at favourable water levels, after }\end{array}$ \\
\hline
\end{tabular}


ECHO: Developing a multi-hazard incident risk assessment tool for swiftwater and flood rescue

close personal inspection and taking all precautions. After a Class VI rapid has been run many times, its rating may be changed to an appropriate Class 5.x rating.

Table 1: International Scale of River Difficulty [1]

\section{Issues with the current scale}

As the ISRD was developed for paddlers such as those involved in rafting and kayaking it still has some application to swiftwater rescue [3], but it also has some limitations to assess risk for urban flood incidents such as those involving low head dams (weirs), flood channels/aqueducts, and rescues from vehicles.

The primary element in determining the river classification is the waves or rapids, though the degree of danger to the swimmer is also considered. However, in some urban flood situations that are highly dangerous there may not be any significant waves or rapids, such as in low head dams or flood channels. By using wave characteristics alone, a highly dangerous fast flowing flood channel with minimal wave characteristics could be designated as Class I.

With respect to flood channels, Gary Seidel (from the Los Angeles Fire Department at the time), developed a 1-4 scale for "Classification of vertical wall flood channels" using the components of speed, depth and hazards (Table 2) [3]. Only one of the three areas (speed, depth or hazard) is required to be present to be assigned to that Class, i.e. a flood channel with a speed of $25 \mathrm{MPH}$ with no obstacles, and less than 10' deep is to be considered Class III. Though simple to use, the limitation to four classes may be confused with the ISRD, where a Class IV using the Seidel classification is considered "extreme", but a Class IV using the ISRD is only considered "advanced".

\begin{tabular}{|l|l|l|l|l|}
\hline Class & Speed & Depth & Hazards & Rescue Option \\
\hline Class I & $0-10 \mathrm{MPH}$ & Less than 10' & $\begin{array}{l}\text { No obstacles. No } \\
\text { gradient. }\end{array}$ & Low risk options usually work \\
\hline Class II & $10-20 \mathrm{MPH}$ & Less than 10' & $\begin{array}{l}\text { Few obstacles. Has a } \\
\text { gradient. }\end{array}$ & $\begin{array}{l}\text { Some low risk options may } \\
\text { work, row options better. }\end{array}$ \\
\hline Class III & $20-30 \mathrm{MPH}$ & $10-20^{\prime}$ & Numerous obstacles & $\begin{array}{l}\text { Higher risk options are usually } \\
\text { required such as helicopters. }\end{array}$ \\
\hline Class IV & $30+\mathrm{MPH}$ & $>20^{\prime}$ & $\begin{array}{l}\text { Stair step channel, low } \\
\text { head or rubber dams } \\
\text { present }\end{array}$ & Extreme caution is required. \\
\hline
\end{tabular}

Table 2: Adaptation of the Seidel Flood Channel Classifications [3] 
ECHO: Developing a multi-hazard incident risk assessment tool for swiftwater and flood rescue

The Seidel classification also mentions low head dams being present, but these can be equally as dangerous as they can be benign, potentially leading to over-estimating the risk which may adversely prevent rescue intervention.

In the United Kingdom, much solid work has gone into a "Weir Assessment System" developed by Rescue 3 Europe and Natural Resources Wales [4]. The system is available in English, French, German, Italian and Hungarian. This assessment system is well regarded and is ideal to assist with risk assessment as part of pre-planning for response to weirs (low head dams). However, it is limited by its complexity for real time rescue risk assessment given it requires five pages of formula to be calculated using the components of hazards, likelihood to cause harm, risk rating and difficulty of rescue to generate a weir rescue difficulty score.

Despite the International Scale of River Difficulty (which is for paddlers on rivers), Seidel flood channel classification system, and the Weir Assessment System, there still is no common risk assessment able to cater generically for the multi-hazard nature of swiftwater and flood rescue. It was this dilemma that prompted the author to develop a coding system for swiftwater incidents that is also capable of generating an overall risk level (colour).

\section{Swiftwater Rescue Incident Risk Assessment Code}

With the popular adoption of the ISRD, it is reasonable to expect that responders to swiftwater incidents should be familiar with the one to six classification system (ISRD), and know that the higher the number, the higher the risk. This creates the basis for the proposed ECHO Swiftwater Rescue Incident Risk Assessment Code (SRIRAC), a three digit code with the first three components making up the risk assessment using a one to six scale. The final component (Outlook) provides an assessment to whether the risk is stable or likely to escalate or de-escalate.

The Swiftwater Rescue Incident Risk Assessment Code has four key components using the Acronym ECHO, namely:

- Entry

- Class

- Hazards

- Outlook

The Entry, Class and Hazards make a three digit code, and is suffixed with an Outlook designation that being an up arrow $(\uparrow)$ to denote the risk is increasing (escalating), or a down arrow $(\downarrow)$ denoting the risk is reducing (de-escalating. Where no arrow is added, this denotes the risk is stable (unlikely to significantly change). 
ECHO: Developing a multi-hazard incident risk assessment tool for swiftwater and flood rescue

Entry

The degree of difficulty for a swiftwater rescuer to enter the water flow (hot zone) is scored (table 3). The degree of difficulty to egress/exit the flow is considered next in the remaining ECHO components as limitations in self-rescue and flow speed for example factor into this.

\begin{tabular}{|l|l|}
\hline 0 & Easy to enter, with little to no effort \\
\hline 1 & Able to enter, may require effort \\
\hline 2 & Able to enter, may require simple assistance \\
\hline 3 & Able to enter, only with simple assistance \\
\hline 4 & Difficult to enter, requires technical assistance \\
\hline 5 & Very difficult to enter, even with technical assistance \\
\hline 6 & Unable to gain entry \\
\hline
\end{tabular}

Table 3: ECHO Entry score

Class

Based on the hydrological features, the flow is assessed in accordance with the ISRD or this simplified table (table 4).

\begin{tabular}{|l|l|}
\hline 0 & No flow (stationery water) \\
\hline 1 & Fast moving, ripples often present \\
\hline 2 & Straight forward hydraulics or waves \\
\hline 3 & Moderate, irregular waves or hydraulics \\
\hline 4 & Intense but predictable waves or hydraulics \\
\hline 5 & Obstructed or very violent rapids or hydraulics \\
\hline 6 & Extreme or non-navigable \\
\hline
\end{tabular}

Table 4: ECHO simplified classification of river 
ECHO: Developing a multi-hazard incident risk assessment tool for swiftwater and flood rescue

\section{Hazards}

Beyond the Entry and Class, the third component of the SRIRAC is Hazards as part of the ECHO acronym and is determined using a supplied table (Table 6). This table provides sub-components of typical hazard categories that are encountered in swiftwater and flood rescue environments. Wherever an environment during assessment meets any of these, the highest scored hazard provides the final score ranging from zero to six to be used in the three digit SRIRAC.

\section{Self Rescue}

Using a typical swiftwater responder (i.e. someone trained against DEFRA Training Module 2 - Water and Flood First Responder [5] or other similar training levels) as the skill base of assessment, the ease of self-rescue is assessed if the responder was to enter the water with basic protective equipment such as helmet and personal floatation device.

\section{Flow Speed (velocity)}

Using average walking, running and sprinting speeds to make assessments easy to perform in the field, the speed of the flow is measured. This can easily be done by throwing a stick or other buoyant object into the flow and seeing how fast it travels, often using a person moving in parallel on the river bank. Some flood channels and aqueducts are capable of very high speeds and this is also factored into the scores available. High speed flow even in shallow water can knock a person off their feet.

\section{Depth}

The depth of water also affects the risk with more surface area of rescuers exposed to flow forces especially on the body (Table 5). The depth also can affect the stability of vehicles and persons due to the changes to buoyancy states (positive, neutral or negative). An example is that a vehicle in shallow water is likely to be more stable than it is in deeper water.

\begin{tabular}{|c|c|c|c|}
\hline $\begin{array}{c}\text { Current Velocity } \\
\text { Kmph/Mph }\end{array}$ & $\begin{array}{c}\text { On Legs } \\
\text { N/lbf }\end{array}$ & $\begin{array}{c}\text { On Body } \\
\text { N/lbf }\end{array}$ & $\begin{array}{c}\text { On Swamped Boat } \\
\text { N/lbf }\end{array}$ \\
\hline $4.8 / 3$ & $75 / 16.8$ & $149 / 33.6$ & $752 / 168$ \\
\hline $9.7 / 6$ & $299 / 67.2$ & $596 / 134$ & $2989 / 672$ \\
\hline $14.5 / 9$ & $672 / 151$ & $1343 / 302$ & $6726 / 1512$ \\
\hline $19.3 / 12$ & $1196 / 269$ & $2392 / 538$ & $11957 / 2688$ \\
\hline
\end{tabular}

Table 5: Force of water (adapted from Swiftwater Rescue, by Slim Ray) [3] 
ECHO: Developing a multi-hazard incident risk assessment tool for swiftwater and flood rescue

\section{Contamination}

It is common for flood water to be contaminated by a wide range of sources. This could include sewage, effluent, chemicals, oils and fuels and many more hazards. Increasing thresholds of water quality is used to assess contamination from the lowest score $(0)$ given to rivers that are known to provide safe drinking water. The risk score increases for this sub-component using the Permissible Exposure Level as the benchmark, though in the field this can be subjective without necessary testing equipment. Though not directly affecting human health, biosecurity considerations are included in the sub-component to acknowledge the need for decontamination processes following exposure above a score of 2 or higher. If water-borne diseases are present such as cholera, typhoid, leptospirosis etc, these automatically render the contamination sub-component a minimum score of 4 .

\section{Wildlife}

In some parts of the world, wildlife may pose a risk to performing swiftwater or flood rescues. Some animals may pose a nuisance such as goats that may take an unwelcome interest in consuming rope anchors, vector-borne diseases such as Malaria, Dengue Fever, Ross River Fever etc, through to apex predators taking the highest risk score.

\section{Temperature}

Cold water affects human performance and survivability in water. The colder the operating environment, the more difficult such rescues can become. The temperature sub-component uses $20^{\circ} \mathrm{C}$ or above as the lowest risk based on normal physiological adaptations occurring in water with a temperature between $20-25^{\circ} \mathrm{C}$, then stepping up to disorders in physiological response occurring below $20^{\circ} \mathrm{C}$, then using $12^{\circ} \mathrm{C}$ as typical sub-tropical average sea temperature, following by using $6^{\circ} \mathrm{C}$ $\left(43^{\circ} \mathrm{F}\right)$ as the next threshold based on the Golden and Tipton [6] decision making model ${ }^{1}$, and the highest risk score assigned to below freezing level (of fresh water). The temperature sub-component factors in decreased physiological performance and survivability. It should be noted the SRIRAC is not used to determine the mode of the incident (i.e. rescue vs. recovery) and guidelines such as Golden and Tipton's [6] (6:30:90) or DEFRA rescue or recovery decision making models [5] should be used.

\section{Imminent Hazards}

Finally, for this sub-component there is as catch-all to ensure imminent or actual hazards not already listed can be scored and factored into the risk assessment.

\footnotetext{
${ }^{1}$ The Golden and Tipton (2011) decision making guide (also known as the 6:30:90 guide) suggests that if the water temperature is warmer than 6 degrees Celsius their survival/resuscitation is extremely unlikely after being submerged for longer than 30 minutes; or 90 minutes in colder water.
} 
ECHO: Developing a multi-hazard incident risk assessment tool for swiftwater and flood rescue

\section{Outlook}

The outlook provides an indication whether the swiftwater rescue risk, based on any of the three primary ECHO components, is likely to increase in risk (escalate) or is likely to decrease in risk (deescalate) in the window of time to carry out the rescue. The outlook uses the up and down arrow symbols respectively, and where the incident is deemed stable (unlikely to change), no symbol is used.

\section{ECHO Colour}

The ECHO colour allows any SRIRAC combination to be easily translated into an overall risk colour. Using a simple five colour approach:

$\begin{array}{lll}\text { Green } & \text { Low } & \text { No component exceeds a score of } 1 . \\ \text { Yellow } & \text { Medium } & \text { Any component scored as } 2 \\ \text { Orange } & \text { Medium Plus } & \text { Any component scored as 3-4 } \\ \text { Red } & \text { High } & \text { Any component scored as } 5 \\ \text { Purple } & \text { Extreme } & \text { Any component scored as } 6\end{array}$

The use of the ECHO colour, following on from assigning a SRIRAC (code) allows for the rapid and simple communication of risk to other public safety professionals. For example, the first arriving responders on scene may code the incident as 352 个, which would be an "ECHO RED ESCALATING" as one of the components scored a 5 (in this example, the flow was Class V). Context can be given to the ECHO Colour such as "ECHO Yellow Low Head Dam".

This can help assign appropriate team types to the incident, with ECHO Green rescues generally being able to be performed using simple wading or shore based techniques. ECHO Yellow may be suitable for simple contact and boat based rescues, and ECHO Orange requiring more specialist expertise. ECHO Red are highly hazardous environments to carry out a rescue from even by experts, and ECHO Purple is extreme where entry to the water to carry out the rescue is un-survivable. 
ECHO: Developing a multi-hazard incident risk assessment tool for swiftwater and flood rescue

\begin{tabular}{|c|c|c|c|c|c|c|c|}
\hline Score & $\begin{array}{l}\text { Self Rescue } \\
\text { (Responder Level) } \\
\text { Assessment }^{2}\end{array}$ & Flow Speed & Depth & Contamination & Wildlife & Temperature & $\begin{array}{l}\text { Imminent Hazards } \\
\text { to rescuer if } \\
\text { exposed }^{3}\end{array}$ \\
\hline 0 & $\begin{array}{l}\text { Self rescue not } \\
\text { needed }\end{array}$ & No flow speed (static) & Less than ankle & Water safe to drink & & $\begin{array}{l}\text { Above } 20^{\circ} \mathrm{C}\left(68^{\circ} \mathrm{F}\right) \text { but } \\
\text { not hot enough to } \\
\text { cause discomfort }\end{array}$ & $\begin{array}{l}\text { No other hazards } \\
\text { identified }\end{array}$ \\
\hline 1 & Self rescue easy & $\begin{array}{l}\text { Less than walking } \\
\text { speed ( } 5 \mathrm{kmph} \text { or } \\
3 \mathrm{mph} \text { ) }\end{array}$ & Shin to thigh height & & $\begin{array}{l}\text { Nuisance wildlife not } \\
\text { posing threat to safety }\end{array}$ & $\begin{array}{l}\text { Between } 12^{\circ} \mathrm{C}\left(43^{\circ} \mathrm{F}\right) \\
\text { and } 20^{\circ} \mathrm{C}\left(68^{\circ} \mathrm{F}\right)\end{array}$ & \\
\hline 2 & $\begin{array}{l}\text { Self rescue may } \\
\text { require effort }\end{array}$ & $\begin{array}{l}\text { In between walking } \\
\text { and running speed }\end{array}$ & $\begin{array}{l}\text { Above thigh up to } \\
\text { chest }\end{array}$ & $\begin{array}{l}\text { Biosecurity hazard not } \\
\text { directly affecting } \\
\text { human safety (ie. } \\
\text { didymo) }\end{array}$ & & $\begin{array}{l}\text { Between } 6^{\circ} \mathrm{C}\left(43^{\circ} \mathrm{F}\right) \\
\text { and } 12^{\circ} \mathrm{C}\left(54^{\circ} \mathrm{F}\right)\end{array}$ & $\begin{array}{l}\text { Hazards that may } \\
\text { hinder rescue (i.e. } \\
\text { turbidity) or damage } \\
\text { property }\end{array}$ \\
\hline 3 & $\begin{array}{l}\text { Self rescue difficult, } \\
\text { may need help }\end{array}$ & $\begin{array}{l}\text { Running speed } \\
(12.5 \mathrm{kmph})\end{array}$ & $\begin{array}{l}\text { Above chest but less } \\
\text { than } 2 \mathrm{~m} \text {. }\end{array}$ & $\begin{array}{l}\text { Contaminants under } \\
\text { their PEL }\end{array}$ & & $\begin{array}{l}\text { Between } 0^{\circ} \mathrm{C}\left(32^{\circ} \mathrm{F}\right) \\
\text { and } 6^{\circ} \mathrm{C}\left(43^{\circ} \mathrm{F}\right)\end{array}$ & $\begin{array}{l}\text { Hazards that may } \\
\text { cause minor injury }\end{array}$ \\
\hline 4 & $\begin{array}{l}\text { Self rescue limited, } \\
\text { help required }\end{array}$ & $\begin{array}{l}\text { Sprinting speed } \\
(25 \mathrm{kmph})\end{array}$ & 2-3 metres deep & $\begin{array}{l}\text { Contaminants } \\
\text { exceeding their PEL or } \\
\text { known water-borne } \\
\text { diseases present }\end{array}$ & $\begin{array}{l}\text { Animals present that } \\
\text { may threaten safety } \\
\text { or carry vector causing } \\
\text { illness }\end{array}$ & Below $0^{\circ} \mathrm{C}\left(32^{\circ} \mathrm{F}\right)$ & $\begin{array}{l}\text { Hazards that may } \\
\text { cause moderate injury }\end{array}$ \\
\hline 5 & $\begin{array}{l}\text { Expert assistance } \\
\text { often required }\end{array}$ & 25-50 kmph & Over 3 metres deep & & & & $\begin{array}{l}\text { Hazards that may } \\
\text { cause major injuries or } \\
\text { death }\end{array}$ \\
\hline 6 & $\begin{array}{l}\text { Rescue may be } \\
\text { impossible or death } \\
\text { imminent }\end{array}$ & Greater than 50kmph & & Contaminants IDLH & $\begin{array}{l}\text { Large predatory } \\
\text { animals likely to } \\
\text { attack }\end{array}$ & & $\begin{array}{l}\text { Imminent hazards } \\
\text { highly likely to cause } \\
\text { death or serious injury }\end{array}$ \\
\hline
\end{tabular}

Table 6: ECHO Hazards table

\footnotetext{
${ }^{2}$ This should also consider self rescue in the context of low head dams, aqueducts/channels, width of flow, etc

${ }^{3}$ May include utilities, engulfment, mechanical entrapment, intakes, strainers, solid ice, debris, suction hazards, vehicle stability etc.
} 
ECHO: Developing a multi-hazard incident risk assessment tool for swiftwater and flood rescue

\section{Examples}

As static images are not realistic to use for risk assessment, a number of video clips located on YouTube have been used to provide examples on how to apply the proposed tool. They have been assessed and assigned an ECHO Code and Colour (table 7).

\begin{tabular}{|c|c|c|c|}
\hline Video QR Code & ECHO Code & ECHO Colour & Comments \\
\hline & 001 & Green & $\begin{array}{l}\text { Easy to walk into the water (hot } \\
\text { zone) scores a } 0 \text {; there is only } \\
\text { stationery water giving the Class } \\
\text { a } 0 \text {; and the water appears to } \\
\text { be between shin and thigh } \\
\text { height scoring a } 1 \text { for hazards. }\end{array}$ \\
\hline & 002 & Yellow & $\begin{array}{l}\text { Easy to walk into the water (hot } \\
\text { zone) scores a } 0 \text {; there is only } \\
\text { stationery water giving the Class } \\
\text { a } 0 \text {; and the water appears to } \\
\text { be between thigh and chest } \\
\text { height scoring a } 2 \text { for hazards. }\end{array}$ \\
\hline & 023 & Orange & $\begin{array}{l}\text { With pedestrian access it scores } \\
0 \text { for entry; the flow has straight } \\
\text { forward hydraulics so it scored } \\
2 \text { for flow (but it could be } \\
\text { reduced to } 1 \text { but erred on the } \\
\text { conservative side); and given } \\
\text { the depth of water to the } \\
\text { vehicle and slow speed, it } \\
\text { scores a } 3 \text { for hazards. No arrow } \\
\text { is provided assuming the flow is } \\
\text { stable. }\end{array}$ \\
\hline
\end{tabular}




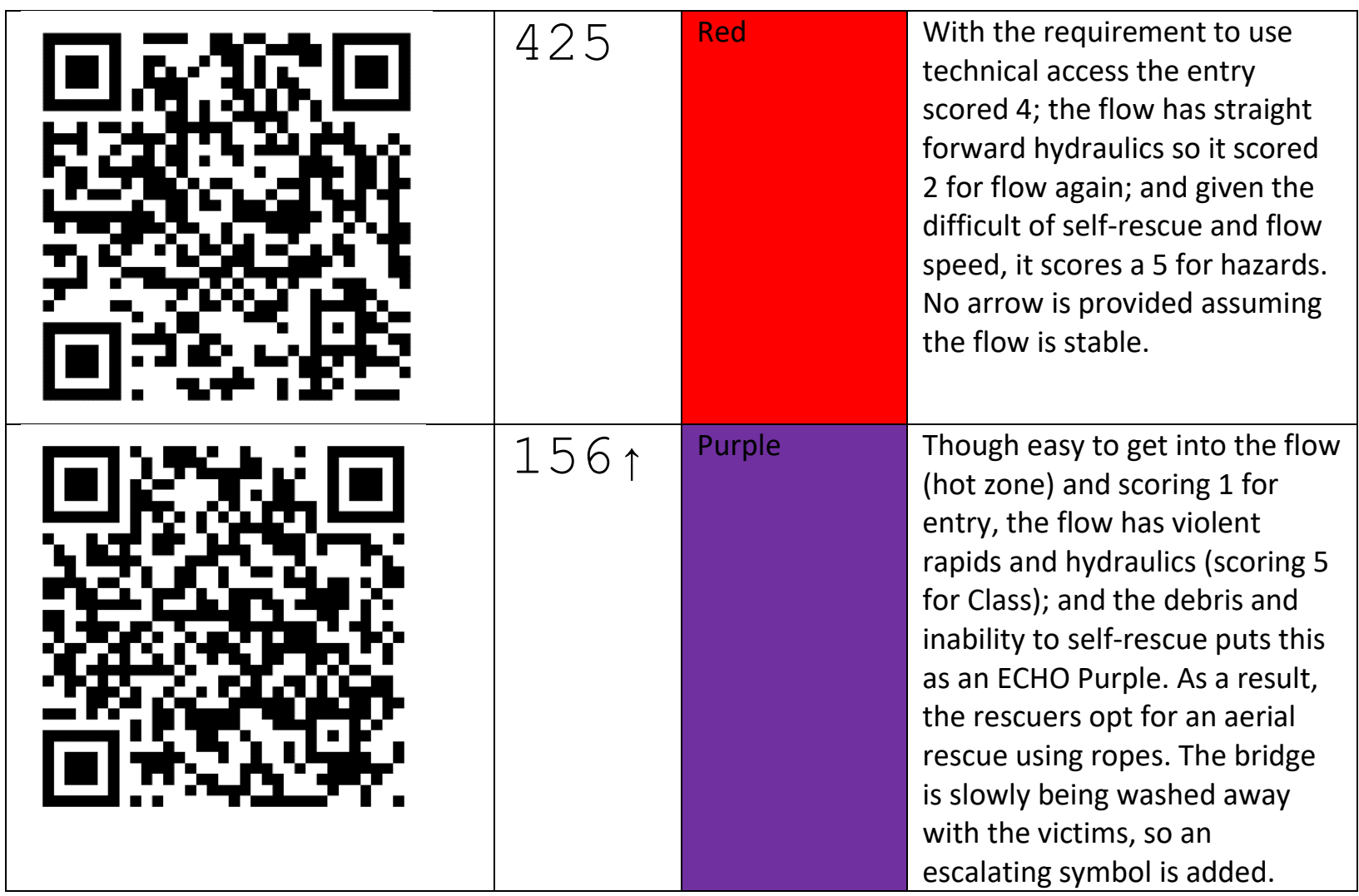

Table 7: ECHO examples

\section{Recommendations and Future Directions}

The development of the EHCO multi-hazard risk assessment tool for swiftwater and flood rescue provides for rapid and simple scoring and coding of incidents. It is distinctly different from the ISRD to avoid confusion when used in a public safety context also. As a concept it requires further testing with end users and discussion with experts. The limitation of the $\mathrm{ECHO}$ tool is that there is likely to be some variance in scoring due to being subjective in nature, however this is no different to the ISRD that also encounters the same limitation of subjectivity especially around the lower levels [7] and the persons perception of risk.

To advance further the ECHO tool, it is recommended that further testing is carried out with both novice and experienced swiftwater rescue practitioners to ascertain the level of variation and ease of use. Other feedback should be sought and then the ECHO tool finalised and published as an easy to use field guide and then piloted for operational use and evaluated further. 
ECHO: Developing a multi-hazard incident risk assessment tool for swiftwater and flood rescue

\section{Conclusion}

When public safety responders arrive at a swiftwater or flood rescue incident, there is currently no simple and rapid system to codify the risk. With so many variables that require to be considered, the $\mathrm{ECHO}$ tool prompts the user to ensure a wide range of factors are considered and appropriately risk scored. A methodical approach in using the tool, should allow for first responders with minimal training to self-identify the risk level of the swiftwater incident and help response coordinators to triage multiple swiftwater incidents. The tool requires further piloting, discussion, and evaluation before being further operationalised, but initial examples show the potential it has to make on-scene risk assessments more robust, regardless of the environmental context.

\section{References}

1. American Whitewater International Scale of River Difficulty Available online:

https://www.americanwhitewater.org/content/Wiki/safety:internation_scale_of_river_diffic ulty (accessed on Nov 21, 2020).

2. Maritime New Zealand Maritime Rules: Part 81 Commercial Rafting Operations 2015.

3. Ray, S. Swiftwater Rescue: A manual for the rescue professional; 2nd ed.; CFS Press: Asheville, NC, 2013; ISBN 978-0-9882435-7.

4. Rescue 3 Europe Weir Risk Assessment Available online: https://www.rescue3europe.com/index.php/student-downloads/weir-risk-assessment (accessed on Nov 21, 2020).

5. DEFRA Flood rescue concept of operations; London, 2019;

6. Tipton, M.J.; Golden, F.S.C. A proposed decision-making guide for the search, rescue and resuscitation of submersion (head under) victims based on expert opinion. Resuscitation 2011, 82, 819-24, doi:10.1016/j.resuscitation.2011.02.021.

7. Watters, R. The Proposed Expanded Class I System of Rating Rivers Available online: http://www.ronwatters.com/classone.htm (accessed on Nov 21, 2020). 
ECHO: Developing a multi-hazard incident risk assessment tool for swiftwater and flood rescue

\section{About the author}

Steve Glassey is a leading expert in swiftwater rescue having been involved in instructing in this discipline for over 20 years. He is appointed by the Coroner's Court of New Zealand as an Expert Witness for swiftwater and flood related fatalities. Having taught around the world including New Zealand, Oman, United States, and Australia, he has been active in developing new approaches to technical rescue including use of TEC REEP $8 \mathrm{~mm}$ cord for swiftwater rescue applications and was awarded the Higgins \& Langley International Flood Rescue Award in 2014 for co-authoring the first body recovery from swiftwater training programme. He was Rescue 3 International's Instructor of the Year, and later became instrumental in founding the International Technical Rescue Association as the inaugural chairman. He is an ITRA Level 3 Swiftwater Instructor (Advanced, Boat, and Vehicle). He continues to pioneer new swiftwater rescue methods such as shore based vehicle stabilisation and other swiftwater vehicle rescue techniques as he has a special interest in this area. He holds a Masters in Emergency Management, is a IAEM Certified Emergency Manager (CEM ${ }^{\circledR}$ ) and is completing a Doctor of Philosophy.

Contact: $\quad$ steve.glassey@hotmail.com

ORCID

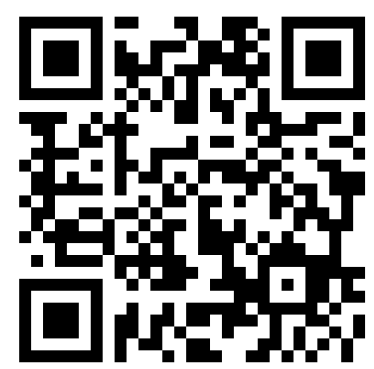

ITRA

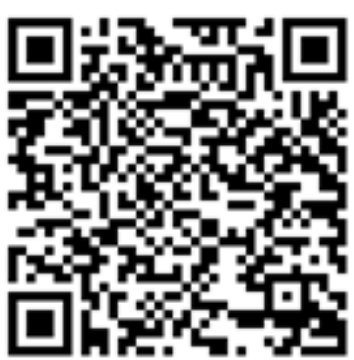

